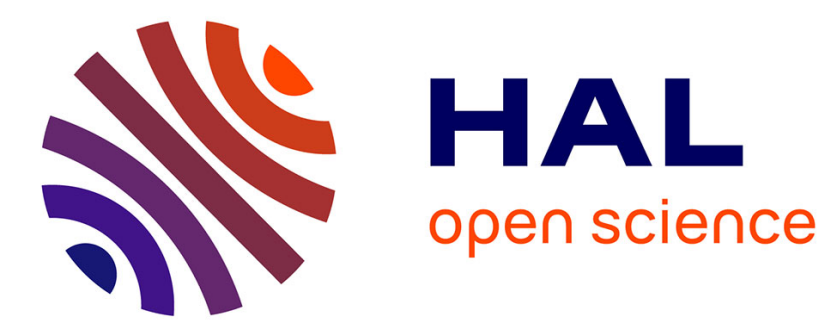

\title{
Review shows that maternal obesity induces serious adverse neonatal effects and is associated with childhood obesity in their offspring
}

\author{
Delphine Mitanchez, Pascale Chavatte-Palmer
}

\section{- To cite this version:}

Delphine Mitanchez, Pascale Chavatte-Palmer. Review shows that maternal obesity induces serious adverse neonatal effects and is associated with childhood obesity in their offspring. Acta Paediatrica, 2018, 107 (7), pp.1156-1165. 10.1111/apa.14269 . hal-02625286

\section{HAL Id: hal-02625286 \\ https://hal.inrae.fr/hal-02625286}

Submitted on 26 May 2020

HAL is a multi-disciplinary open access archive for the deposit and dissemination of scientific research documents, whether they are published or not. The documents may come from teaching and research institutions in France or abroad, or from public or private research centers.
L'archive ouverte pluridisciplinaire HAL, est destinée au dépôt et à la diffusion de documents scientifiques de niveau recherche, publiés ou non, émanant des établissements d'enseignement et de recherche français ou étrangers, des laboratoires publics ou privés.

$$
\text { Copyright }
$$


Article type : Review Article

Review shows that maternal obesity induces serious adverse neonatal effects and is associated with childhood obesity in their offspring

Running title: Maternal obesity and neonatal and childhood outcomes

Delphine MITANCHEZ ${ }^{1}$, Pascale CHAVATTE-PALMER ${ }^{2}$

${ }^{1}$ Department of Perinatality, APHP, GHUEP, Armand Trousseau Hospital, Paris and Faculty of Medicine, Sorbonne University, Paris 06, Paris, France.

${ }^{2}$ UMR BDR, INRA, ENVA, Université Paris Saclay, 78350, Jouy en Josas, France

${ }^{*}$ Corresponding author: Delphine Mitanchez

Department of perinatology, neonatal unit,

Armand Trousseau Hospital,

26 avenue du Docteur Arnold Netter, 75571 Paris Cedex 12, FRANCE

E-mail: delphine.mitanchez@aphp.fr

This article has been accepted for publication and undergone full peer review but has not been through the copyediting, typesetting, pagination and proofreading process, which may lead to differences between this version and the Version of Record. Please cite this article as doi: 10.1111/apa.14269

This article is protected by copyright. All rights reserved. 


\section{Abbreviations}

BMI: body mass index

OR: odd ratio

Cl: confidence interval

GD: gestational diabetes

LGA: large for gestational age

\section{Abstract}

Aim

Obesity at the start of pregnancy has been rising worldwide, increasing the risk of maternal complications. We reviewed the independent effects of maternal obesity during pregnancy on neonatal adverse outcomes and the risk of childhood obesity and adverse cardiometabolic profiles.

\section{Methods}

We searched MEDLINE for papers published in English between December 2007 and November 2017, focusing primarily on human studies published in the last five years. However, we also chose to highlight examples derived from model animals that could bring mechanistic insight and preventive and therapeutic avenues.

\section{Results}

Our review showed that maternal obesity had independent effects on neonatal adverse outcomes such as macrosomia, perinatal mortality and birth defects. Maternal obesity alone increased the risks for adverse neonatal outcomes, including macrosomia, perinatal 
mortality, induced preterm birth and birth defects. In association with excess gestational weight gain, mainly early in pregnancy, increased the risks of childhood obesity, higher fat mass and, to a smaller extent, adverse cardio-metabolic profiles. Animal models highlighted sexually dimorphic responses to maternal obesity.

\section{Conclusion}

Maternal obesity induced serious adverse neonatal effects and was associated with childhood obesity in their offspring. The peri-conceptional period is critical for metabolic programming and obese women need close monitoring from conception.

Key words:

Child obesity, gestational diabetes, gestational weight gain, metabolic programming, neonatal outcomes

Key notes:

- This study reviewed the independent effects of maternal obesity during pregnancy on neonatal adverse outcomes and the risk of childhood obesity and adverse cardiometabolic profiles.

- We found that maternal obesity had serious adverse neonatal effects, such as macrosomia, perinatal mortality and birth defects, and was associated with childhood obesity in their offspring.

- The peri-conceptional period is critical for metabolic programming and obese women need close monitoring from conception.

This article is protected by copyright.All rights reserved. 


\section{INTRODUCTION}

The incidence of obesity during pregnancy has been rising worldwide, in parallel with the global increase in obesity in the general population. In most developing countries, the prevalence of overweight, defined as a body mass index (BMI) of at least $25 \mathrm{~kg} / \mathrm{m}^{2}$, in women aged 20-49 years residing in both urban and rural areas is higher than that of underweight women, with a BMI of less than $18.5 \mathrm{~kg} / \mathrm{m}^{2}$. The median ratio of overweight to underweight is $5.8: 1$ and of $2.1: 1$ in urban and rural areas, respectively (1). In the United States, in 2009, more than one in five pregnant women was obese, with a BMI of at least 30 $\mathrm{kg} / \mathrm{m}^{2}$, across almost every age and racial ethnic group (2). In European countries, the prevalence of maternal obesity has been reported to be $7-25 \%$ and it seems to be strongly related to social and educational inequalities (3). As a consequence, maternal obesity has become a major public health concern because of the increased risks for adverse outcomes for both the mother and child. Indeed, maternal obesity has been associated with multiple adverse outcomes, including preeclampsia, altered fetal growth, neonatal morbidity and childhood obesity. Despite the fact that obesity is often accompanied by co-morbidities such as gestational diabetes (GD), these have not always been controlled for the studies that have been carried out. Therefore, the main aim of the this review was to examine the comorbidities associated with maternal gestational obesity and systematically review the neonatal adverse outcomes and the risk of obesity and cardio-metabolic risks in childhood associated with maternal obesity and associated comorbidities per se during pregnancy. We also decided to provide selected information from animal models to provide an insight into the putative mechanisms and potential prevention strategies that could be used in humans.

This article is protected by copyright.All rights reserved. 


\section{METHODS}

The MEDLINE database was systematically reviewed for papers on human subjects published in English between December 2007 and November 2017, with a particular focus on studies published in the last past years of the study period. We used the search terms maternal obesity, pre-eclampsia, diabetes mellitus, gestational weight gain, infant, newborn, "mortality, macrosomia, birth weight, preterm, congenital anomalies, population attributable risk, childhood, childhood obesity and adiposity and childhood outcomes. The review did not exclude commonly referenced and highly regarded older publications. We also included relevant references from the reference lists of the papers identified by our search strategy. We gave priority to meta-analyses and systematic reviews, randomised control trials and large cohort and case-control studies that were judged relevant. Finally, in order to limit the number of references to the journal's requirements, if several references indicated the same results, we only cited the most recent in the last five years of the study period.

The results are organised in the first section, which focuses on maternal comorbidities, and the second section, which is dedicated to neonatal and childhood outcomes. In the following text, unless stated otherwise, overweight refers to a BMI of more than 25 and less than 30 obesity to a BMI of at least 30 and severe obesity to a BMI of at least 35 . Infant death is defined as mortality between birth and one year of age and large for gestational age (LGA) is a birth weight above the $90^{\text {th }}$ percentile for gestational age. Odds ratios $(\mathrm{OR})$ and Zscores are presented as the mean value followed by the $95 \%$ confidence interval $(95 \% \mathrm{Cl})$ when available.

In the second part of this paper, the aim was not to perform a systematic review, but to highlight significant concepts and treatment or preventive avenues to be tested in humans, as a starting point for further human studies and preventive strategies.

This article is protected by copyright.All rights reserved. 


\section{Maternal conditions associated with obesity and adverse outcomes}

Maternal obesity is associated with a significant increase in maternal morbidities during pregnancy and some of these, such as GD and hypertension, alter fetal health and are independently associated with adverse neonatal outcomes.

\section{Preeclampsia}

Pre-eclampsia is defined as the occurrence of de novo hypertension with blood pressure $>140 / 90 \mathrm{mmHg}$ and proteinuria $\geq 0.3 \mathrm{~g} / 24$ hours after 20 weeks of gestation. There is a clear relationship between increasing BMl and the risk of preeclampsia. A meta-analysis of 29 prospective cohort studies demonstrated a risk ratio for preeclampsia of $2.68(95 \% \mathrm{Cl}$ 2.40-3.00), for obese women and $3.43(95 \% \mathrm{Cl} 2.59-4.55)$ for women with severe obesity. That study concluded that maternal adiposity was an independent risk factor for preeclampsia in both nulliparous and multiparous women (4). Another systematic review reported that obese women were 3-10 times more likely to have pre-eclampsia, but that the exact biological causal pathway remained poorly defined (5). To date, the specific effect of preeclampsia on the fetus and neonate in an obese pregnancy has not been addressed.

\section{Diabetes}

The association between maternal obesity and GD has been reported by many studies. A systematic review of observational studies published between 1977 and 2007 found an OR of $3.01(95 \% \mathrm{Cl} 2.34-3.87)$ for obese women and 5.55 (4.27-7.21) for severely obese women, when compared to women of normal weight (6). In a multi-ethnic population where the prevalence of maternal obesity was $14 \%$, the population attributable risk fraction indicated that one-third of the diabetes cases could have been avoided if all the obese women had a normal BMI (7).

This article is protected by copyright. All rights reserved. 
Therefore, obesity and diabetes are linked. Indeed, the maternal metabolic environment in obese women is characterised by a greater insulin resistance at the beginning of pregnancy compared to normal weight women. Cytokines produced by the adipose tissue affect post receptor insulin signalling, thus enhancing insulin resistance during pregnancy and leading to maternal hyperinsulinaemia, hyperglycaemia and GD. Nevertheless, a report based on data from the Hyperglycemia and Adverse Pregnancy Outcome study showed that maternal GD and obesity were independently associated with adverse pregnancy outcomes and that the combination of the two had a greater impact than either one alone (8).

Another important point is that diabetes may also precede pregnancy, as growing numbers of pregnant women are affected by type 2 diabetes, diagnosed either before or during pregnancy. In an Australian cohort of 138 pregnancies with type 2 diabetes, $80 \%$ of the women who were affected were overweight or obese (9).

Once diagnosed, diabetes is treated and glycaemic control levels are targeted. In obese women with GD, achieving the targeted levels of glycaemic control has only been associated with better outcomes in women treated with insulin. In one study, the obese women who achieved their targeted levels of glycaemia just by dieting had a two to three times higher risk of adverse pregnancy outcomes than normal weight women with well controlled GD (10).

\section{Gestational weight gain}

The Institute of Medicine recommends that gestational weight gain is limited to $5-9 \mathrm{~kg}$ for obese women. Despite this, $47-72 \%$ of obese women gain more weight than recommended and excessive gestational weight gain in obese pregnancies is associated with higher birth weight (11) and an increased risk of preterm birth (12).

This article is protected by copyright.All rights reserved. 
A meta-analysis that aimed to evaluate the effects of interventions based on diet and physical activity, showed that these interventions reduced gestational weight gain compared to controls by a mean of $-0.70 \mathrm{~kg}(95 \% \mathrm{Cl}-0.92$ to $-0.48 \mathrm{~kg})$. Interventions do not significantly reduce offspring complications, irrespective of maternal BMI, although those that are mainly based on physical activity have been shown to reduce the odds for GD (13). Finally, although dietary and physical activity counselling at the pre-conceptional stage has been shown to result in a reduction in gestational weight gain, there was no effect on gestational week of delivery nor on infant birth weight in overweight, obese and severely obese women (14).

Bariatric surgery is increasingly used as an effective treatment for obesity and reduces weight before pregnancy and gestational weight gain. One study showed that women who had undergone bariatric surgery had lower risks of preeclampsia, GD and macrosomia, but the risk of small neonates and preterm birth was increased (15).

\section{Maternal obesity and perinatal outcomes}

The perinatal outcomes following maternal obesity are schematically represented in Figure 1.

\section{Maternal obesity and fetal growth}

The relationship between maternal obesity and high birth weight is well documented. Indeed, several meta-analyses have demonstrated that maternal obesity was associated with excessive fetal growth, with an average increased risk of 2.5 to three-fold (16-19) (Table 1). Nevertheless, it seems that gestational weight gain above the recommended limits contributes more to LGA births than being obese, with population attributable fractions of $15.9 \%$ and $8.9 \%$, respectively $(20)$.

This article is protected by copyright.All rights reserved. 
Data concerning the association between maternal obesity and low birth weight are controversial, with both reports of decreased and moderately increased risk (Table 1) (16, 19, 21).

\section{Foetal and neonatal mortality}

Maternal overweight and obesity are the highest ranking modifiable risk factors for stillbirth in high-income countries, with a population attributable fraction of $8-18 \%$, contributing to around 8,000 stillbirths at 22 weeks of gestation or more per year. The population attributable fraction for pre-existing diabetes in high-income countries is $3.3-4.7 \%$, contributing to around 2,200 stillbirths per year (22).

Even a modest increase in maternal BMI has been associated with increased risks of fetal, perinatal, neonatal or infant deaths. One meta-analysis showed that the relative risk for each five-unit unit increase in maternal BMI was $1.21(95 \% \mathrm{Cl} 1.09-1.35)$ for fetal death, 1.24 $(95 \% \mathrm{Cl} 1.18-1.30)$ for stillbirth, $1.16(95 \% \mathrm{Cl} 1.00-1.35)$ for perinatal death, $1.15(95 \% \mathrm{Cl}$ 1.07-1.23) for neonatal death and $1.18(95 \% \mathrm{Cl} 1.09-1.28)$ for infant death (23).

Most studies did not consider whether GD or other maternal or fetal complications were present in their analysis of mortality rates. In a large cohort study that excluded pregnancies with malformations and pre-gestational diabetes, maternal obesity was associated with increased risks of fetal and infant death with ORs of 2.32 (95\%1.64-3.28) and 1.97 (1.13-3.45), respectively. Moreover, for each one-point increase in maternal BMI over 23 $\mathrm{kg} / \mathrm{m}^{2}$, the risk increased by $7 \%$ fetal death and $6 \%$ for infant death (24). The results were the same when the women with hypertension were excluded.

The mechanisms behind this excess mortality were not identified. Maternal obesity, however, was shown to be associated with neonatal complications, such as post-term birth, that increase the risks of fetal and perinatal death. One meta-analysis showed a linear association between the risk of birth after 41 weeks of gestation and maternal BMI: the OR for each five-unit increase in BMI was $1.13(95 \% \mathrm{Cl} 1.05-1.21)(25)$.

This article is protected by copyright.All rights reserved. 


\section{Prematurity}

The risk of preterm birth before 37 weeks was not, or just slightly, increased by maternal obesity, with a population attributable fraction for high BMI of less than $5 \%(20)$. In contrast, the risk of preterm birth before 33-32 weeks was significantly increased (Table 2). Nevertheless, the latter risk concerned induced preterm, but not spontaneous, preterm birth $(21,26)$. This could be expected, as obese women are more likely to develop preeclampsia and GD, which often lead to elective preterm delivery.

\section{Birth defects}

The increased risk of fetal malformations in obese pregnant women has been reviewed in detail. Studies showed that obesity doubled the risk of neural tube defects, especially spina bifida, increased the risk of cardiovascular malformations and limb abnormalities by $30 \%$, the risk of a cleft lip and, or, palate by $20 \%$ and anorectal atresia and hydrocephalus by $50-70 \%(27,28)$. Maternal obesity has also been associated with about a two-fold increased risk of omphalocele and diaphragmatic hernia (29). Conversely, the risk of laparoschisis is significantly decreased in obese women, probably because of the influence of maternal age, as the prevalence of obesity increases with age, whereas laparoschisis affects younger women.

Most of these malformations have also been described in cases of pre-GD, which raises the issue of abnormal maternal glycaemic balance at the beginning of pregnancy, and in cases of undiagnosed type 2 diabetes. Nevertheless, when cases with pre-GD are excluded, the risk of cardiac malformations or neural tube defects are only slightly changed (28). Although omphalocele and diaphragmatic hernia are not usually reported in cases of maternal diabetes, associations between malformations and maternal obesity teratogenicity factors directly associated with maternal obesity deserve to be studied further.

This article is protected by copyright.All rights reserved. 


\section{Other adverse neonatal outcomes}

A reduced Apgar score of less than seven at five minutes has been associated with maternal obesity with an OR of 1.40 (95\% Cl 1.27-1.54), but neonatal cord pH has not (30). In a large cohort study that included 1,423,929 term neonates from obese or normal-weight mothers, the adjusted hazard ratios for cerebral palsy were 1.28 (95\% Cl 1.11-1.47) for a maternal BMI of 30 to $34.9,1.54(95 \% \mathrm{Cl} 1.24-1.93)$ for 35 to 39.9 and 2.02 (95\% Cl 1.46-2.79) for BMI over 40 . An estimated $45 \%$ of the association between maternal BMI and rates of cerebral palsy in full-term children was reported to be mediated through asphyxia-related neonatal morbidity (31).

One study reported that when mothers were obese, their infants had a significantly higher risk of being admitted to the neonatal intensive care unit, with an OR of $1.91(95 \% \mathrm{Cl}$ 1.60-2.29) (16). Moreover, another study found a significant relationship between maternal obesity and respiratory distress (OR 1.71, 95\% Cl 1.38-2.11), resuscitation (OR 1.75, 95\% Cl 1.26-2.43) and increased tube feeding requirements (OR 1.51, 1.08-2.10) (19).

A large cohort study showed that, compared to neonates born to women who were normal weight, those born to women with a BMI of more than 40 had an increased risk of a birth injury to the peripheral nervous system and to the skeleton, with ORs of $3.80(95 \% \mathrm{Cl}$ 12.83-5.12) and $2.59(95 \% \mathrm{Cl} 2.10-3.21)$, respectively, and an increased risk of hypoglycaemia of $3.48(95 \% \mathrm{Cl} 3.20-3.78)(32)$. The latter may have been related to maternal diabetes, which is frequently associated with obesity, as the adjustment for maternal blood glucose levels performed in another study eliminated this relationship (33).

This article is protected by copyright.All rights reserved. 


\section{Effect of maternal obesity on health of offspring during childhood}

The concept of the early origins of adult disease was first developed by David Barker in the late 1980s. He observed that cardiovascular risk, as well as the risk of diabetes and metabolic syndrome in adulthood, was increased in low birth weight individuals. This resulted in his hypothesis that restricted in utero nutrition permanently alters tissue structures and functions, and hence metabolism, increasing the risk of cardiovascular and metabolic disorders in adulthood (34). Since then extensive reviews have shown that maternal obesity during pregnancy has also been shown to contribute to the developmental origins of health and disease (35).

The following text explores the relative contribution of maternal pre-pregnancy BMI, gestational weight gain and diabetes, to body composition and cardio-metabolic disorders of children born to obese mothers.

\section{Childhood obesity}

When women are overweight before pregnancy this doubles the risk of their offspring being overweight or obese and obese mothers treble the risk of offspring overweight or obesity (18). Excessive gestational weight gain has also been associated with an increased risk of offspring obesity of up to $40 \%$ (36). The highest risk was observed during childhood (OR $1.91,95 \% \mathrm{Cl} 121-3.02$ ) with a subsequent decrease (OR 1.32, $95 \% \mathrm{Cl} 1.14-1.53$ ) from five to 17 years of age $(36)$.

Many studies built on population-based prospective cohorts in different populations, from early pregnancy or birth, have reported that offspring adiposity was positively associated with maternal BMI and gestational weight gain (Table 3) (37-47).

Nevertheless, the timing of any gestational weight gain during pregnancy is important. Several studies showed that high early pregnancy weight gain was associated with high BMI and adiposity in offspring during childhood. Indeed, any weight gain in the first 14 weeks of gestation has been shown to be incrementally associated with increased offspring adiposity, 
whereas between 14 and 36 weeks, only a gestational weight gain of more than $500 \mathrm{~g}$ per week has been associated with increased offspring adiposity (47). In line with these findings, the Generation R study found that weight gain in early pregnancy was associated with childhood BMI and adiposity, independent of maternal pre-pregnancy BMI and later pregnancy weight gain (45).

\section{Childhood cardio-metabolic profile}

Adverse cardio-metabolic profiles that have been associated with maternal obesity or excessive gestational weight gain include increased blood pressure, impaired lipid profile, insulin resistance or elevated inflammatory markers $(40,42-45,47)$. However, these associations have not been shown to be very strong and they may have been mainly mediated by offspring adiposity. In the Generation R study, the clustering of cardio-metabolic risk factors was three-fold higher in the offspring of obese mothers, compared to children from normal weight mothers, and 1.7-fold higher in offspring from women who gained excess weight in early pregnancy (45).

\section{Effect of maternal obesity and maternal diabetes or macrosomia on child health}

One meta-analysis found a significantly increased Z-score of $0.28(956 \% \mathrm{Cl} 0,09-0,47)$ when there was maternal diabetes, but this is no longer apparent after the data were adjusted for maternal BMI (48). These results provide support for the suggestion that GD cannot be evaluated as an independent risk factor for childhood overweight or obesity without accounting for potential confounding maternal obesity. Furthermore, it is important to consider the timing of the mother's exposure to diabetes during pregnancy. It is possible that pre-existing type 2 diabetes at the beginning of a pregnancy does not have the same impact as GD.

This article is protected by copyright.All rights reserved. 
Macrosomia has also been shown to increase the risk of obesity, type 2 diabetes and metabolic syndrome in offspring. One study reported a two-fold increase in the risk of obesity in offspring when the birth weight was more than $4 \mathrm{~kg}(49)$. The prevalence of metabolic syndrome in children between the ages of $6-11$ was $50 \%$ in those born LGA to diabetic mothers, $21 \%$ in those born to diabetic mothers with normal birth weights and $29 \%$ in those born LGA born to non-diabetic mothers. In that study, a regression analysis demonstrated that LGA status and maternal obesity each increased the risk of metabolic syndrome by approximately two-fold, while maternal diabetes was not independently significant (50). These results mean that children who are LGA at birth and exposed to an intrauterine environment of either diabetes or maternal obesity face an increased risk of developing metabolic syndrome. Moreover, maternal obesity on its own, exclusive of a GD diagnosis, may affect offspring outcome regardless of birth weight.

\section{What can we learn from animal models?}

As stated above, prospective cohort studies have highlighted associations between maternal obesity and gestational weight gain and the risk of obesity or adverse metabolic profile in childhood. However, they have not supported conclusions about causality. Indeed, other factors involved in offspring health, such as maternal smoking or vitamin D deficiency, have been associated with childhood obesity. These factors have often been observed during obese pregnancies, but have mostly been overlooked (39). Moreover, many postnatal expositions, in particular breastfeeding duration and the age when solid food is introduced, have been shown to influence the risk of higher childhood adiposity (51).

Due to the experimental control of developmental conditions, and the short life cycle of many animals, animal models have been widely studied to try and decipher mechanisms linking maternal and offspring obesity. Nevertheless, extreme diets, such as those with $60 \%$ fat in mice, are usually needed to induce maternal obesity in rodents, as model animals will often 
adjust their feed intake to maintain their body condition. Moreover, it is critical to understand the physiological similarities and differences between humans and animal models, including non-rodent animals, in order to infer significant information from studies generated in animals (52). Since considerable data are available on animal models, the aim of the following section is to shed light on key observations and treatment opportunities suggested by studies using animal models, without attempting to exhaustively review the literature.

\section{Effects of maternal obesity and diabetes during gestation in animal models}

In contrast to what is commonly expected, excess maternal nutrition or maternal obesity in animals has usually been shown to lead to fetal growth restriction rather than excess fetal growth, as a result of impaired placental function (53). However, macrosomia and, or, increased neonatal BMI has been observed in offspring born to obese sheep (54) and nonhuman primates (55). Nevertheless, feeding an obesogenic diet to females before and during pregnancy generally increased the incidence of obesity and insulin resistance in offspring $(56,57)$. It is important to note that GD does not occur spontaneously in most animals, although increased insulin resistance is a common feature during pregnancy. Thus, GD may be induced through pharmaceutical intervention, with the use of streptozotocin or alloxan to destroy maternal pancreatic beta-cells before pregnancy or genetic modification or maternal infusion with glucose at specific stages of pregnancy. A review on maternal obesity reported that macrosomia was not a consistent finding in offspring born to diabetic dams, but impaired glucose homeostasis and beta cell dysfunction were reported in the offspring (52).

\section{Key observations}

The key observations in animal models include sexual dimorphism in feto-placental responses and long-term offspring outcomes in response to maternal obesity (58). The placenta, of fetal origin, is the active maternal-fetal interface and a key actor in programming through its nutrient sensing, nutrient transfer and endocrine function (59). The sexually dimorphic gene expression responses demonstrated in the mouse placenta, in response to 
the maternal diet (60), have now been confirmed in other species, together with physiological observations (58). It is interesting to observe that relatively few of the above cited studies in humans considered fetal or child sex and omitting this factor may wipe out important observations. Indeed, we showed in a prospective human cohort study that neonatal fat mass and cord serum leptin concentrations were increased in girls born to obese women compared to normal weight women, but not in boys (61).

Many studies in animals demonstrate the importance of the pre-conceptional and periconceptional periods in the programming of offspring health $(62,63)$. In particular, maternal obesity has been associated with distinct gene expression profiles in the uterus of obese female rats, affecting inflammatory and lipid metabolism pathways and associated with lipid accumulation (64). Gene expression in early and late pre-implantation embryo development has also been shown to be affected by maternal obesity and a high fat diet in both rats and rabbits (64). Moreover, embryo transfer experiments in mice have shown that pregestational and peri-conceptional maternal obesity independently affect offspring development (65), thus highlighting the importance of these periods when considering potential corrective interventions.

\section{Treatment or prophylactic opportunities}

Although preconceptional obesity directly affects offspring development, weight loss before pregnancy has been shown to prevent obesity-induced transcriptional changes in the placenta, although the offspring phenotype was still affected by previous maternal obesity (66).

Modifications in dietary macro-nutriments and micro-nutriments to modify placental function and possibly modulate fetal growth and metabolism have been explored. Since high-fat and obesogenic diets have been shown to alter epigenetic marks in the fetus and placenta (67), maternal intake of methyl donors such as folic acid and methionine could modify the 
methylation of fetal metastable epialleles, as demonstrated in both mice and humans (68, $69)$.

Maternal obesity affects placental vascularisation and function. Thus, maternal supplementation with amino-acids, such as citrulline or arginine, that improve placental function through multiple mechanisms, could be used for maternal treatment. Indeed, one study reported that citrulline supplements improved placental function in rats and enhanced fetal growth (70), whereas arginine supplements improved insulin sensitivity in dams fed a high-fat diet (71). Preliminary clinical data has already indicated that arginine supplements may also be beneficial for obese pregnant women (72).

Maternal obesity is also clearly accompanied by systemic inflammation. One study showed that increasing the $n-3 / n-6$ polyunsaturated fatty acid ratio in the maternal plasma of obese mice reduced maternal inflammation and prevented adverse offspring metabolic outcomes (73).

Finally, very encouraging results have been obtained using maternal exercise before and, or, during pregnancy in obese female rats and improving offspring outcomes until old age in male offspring (74). Exercise strategies have been attempted in obese women, but compliance may be an issue.

\section{CONCLUSION}

There is no doubt that maternal obesity during pregnancy induces short-term effects on the fetus and the neonate, but it also affects health during childhood, independently of other maternal comorbidities (Figure 1). The effects on fetal growth, birth defects and the incidence of perinatal death have been particularly striking. There is also growing evidence, not detailed here, that maternal obesity has an impact on the long-term metabolic and cardiovascular health of their offspring, as well as their mental health, through direct effects

This article is protected by copyright.All rights reserved. 
of nutrition on epigenetic mechanisms (75). Prevention strategies are urgently needed and the data shown here indicate that improving physical activity in obese women is beneficial and that bariatric interventions prior to pregnancy must also be considered. Data obtained by animal and human studies also call for the management of obese women, starting from the peri-conceptional period or even before. Moreover, work on animals and work on humans indicate that different effects could be expected between boys and girls. These observations, if confirmed in humans, could lead to the development of specific maternal nutritional strategies that depend on the sex of their fetus. Finally animal data suggest that further studies on targeted nutritional interventions in obese pregnancies must be performed.

\section{CONFLICTS OF INTEREST}

The authors have no conflicts of interest to declare.

\section{References}

1. Mendez MA, Monteiro CA, Popkin BM. Overweight exceeds underweight among women in most developing countries. Am J Clin Nutr 2005; 81: 714-21.

2. Fisher SC, Kim SY, Sharma AJ, Rochat R, Morrow B. Is obesity still increasing among pregnant women? Prepregnancy obesity trends in 20 states, 2003-2009. Prev Med 2013; 56: 372-8.

3. Devlieger R, Benhalima K, Damm P, Van Assche A, Mathieu C, Mahmood T, et al. Maternal obesity in Europe: where do we stand and how to move forward?: A scientific paper commissioned by the European Board and College of Obstetrics and Gynaecology (EBCOG). Eur J Obstet Gynecol Reprod Biol 2016; 201: 203-8.

4. Wang Z, Wang P, Liu H, He X, Zhang J, Yan H, et al. Maternal adiposity as an independent risk factor for pre-eclampsia: a meta-analysis of prospective cohort studies. Obes Rev 2013; 14: 508-21. 5. Salihu HM, De La Cruz C, Rahman S, August EM. Does maternal obesity cause preeclampsia? A systematic review of the evidence. Minerva Ginecol 2012; 64: 259-80.

This article is protected by copyright. All rights reserved. 
6. Torloni MR, Betran AP, Horta BL, Nakamura MU, Atallah AN, Moron AF, et al. Prepregnancy $\mathrm{BMI}$ and the risk of gestational diabetes: a systematic review of the literature with meta-analysis. Obes Rev 2009; 10: 194-203.

7. Oteng-Ntim E, Kopeika J, Seed P, Wandiembe S, Doyle P. Impact of obesity on pregnancy outcome in different ethnic groups: calculating population attributable fractions. PLoS One 2013; 8: e53749.

8. Catalano PM, McIntyre HD, Cruickshank JK, McCance DR, Dyer AR, Metzger BE, et al. The hyperglycemia and adverse pregnancy outcome study: associations of GDM and obesity with pregnancy outcomes. Diabetes Care 2012; 35: 780-6.

9. Abell SK, Boyle JA, de Courten B, Soldatos G, Wallace EM, Zoungas S, et al. Impact of type 2 diabetes, obesity and glycaemic control on pregnancy outcomes. Aust N Z J Obstet Gynaecol 2017; 57: 308-14.

10. Langer O, Yogev $\mathrm{Y}$, Xenakis EM, Brustman L. Overweight and obese in gestational diabetes: the impact on pregnancy outcome. Am J Obstet Gynecol 2005; 192: 1768-76.

11. Faucher MA, Barger MK. Gestational weight gain in obese women by class of obesity and select maternal/newborn outcomes: A systematic review. Women Birth 2015; 28: e70-9.

12. Faucher MA, Hastings-Tolsma M, Song JJ, Willoughby DS, Bader SG. Gestational weight gain and preterm birth in obese women: a systematic review and meta-analysis. BJOG 2016; 123: 199206.

13. International Weight Management in Pregnancy Collaborative G. Effect of diet and physical activity based interventions in pregnancy on gestational weight gain and pregnancy outcomes: meta-analysis of individual participant data from randomised trials. BMJ 2017; 358: j3119.

14. Agha M, Agha RA, Sandall J. Interventions to reduce and prevent obesity in pre-conceptual and pregnant women: a systematic review and meta-analysis. PLoS One 2014; 9: e95132.

15. Yi XY, Li QF, Zhang J, Wang ZH. A meta-analysis of maternal and fetal outcomes of pregnancy after bariatric surgery. Int J Gynaecol Obstet 2015; 130: 3-9.

This article is protected by copyright.All rights reserved. 
16. Liu $P, X u L$, Wang $Y$, Zhang $Y$, Du $Y$, Sun $Y$, et al. Association between perinatal outcomes and maternal pre-pregnancy body mass index. Obes Rev 2016; 17: 1091-102.

17. Gaudet L, Ferraro ZM, Wen SW, Walker M. Maternal obesity and occurrence of fetal macrosomia: a systematic review and meta-analysis. Biomed Res Int 2014; 2014: 640291.

18. Yu Z, Han S, Zhu J, Sun X, Ji C, Guo X. Pre-pregnancy body mass index in relation to infant birth weight and offspring overweight/obesity: a systematic review and meta-analysis. PLoS One 2013; 8: e61627.

19. Heslehurst N, Simpson H, Ells LJ, Rankin J, Wilkinson J, Lang R, et al. The impact of maternal BMI status on pregnancy outcomes with immediate short-term obstetric resource implications: a meta-analysis. Obes Rev 2008; 9: 635-83.

20. Dzakpasu S, Fahey J, Kirby RS, Tough SC, Chalmers B, Heaman MI, et al. Contribution of prepregnancy body mass index and gestational weight gain to adverse neonatal outcomes: population attributable fractions for Canada. BMC Pregnancy Childbirth 2015; 15: 21.

21. McDonald SD, Han Z, Mulla S, Beyene J. Overweight and obesity in mothers and risk of preterm birth and low birth weight infants: systematic review and meta-analyses. Bmj 2010; 341: c3428.

22. Flenady V, Koopmans L, Middleton P, Froen JF, Smith GC, Gibbons K, et al. Major risk factors for stillbirth in high-income countries: a systematic review and meta-analysis. Lancet 2011; 377: 1331-40.

23. Aune D, Saugstad OD, Henriksen T, Tonstad S. Maternal body mass index and the risk of fetal death, stillbirth, and infant death: a systematic review and meta-analysis. Jama 2014; 311: 1536-46. 24. Tennant PW, Rankin J, Bell R. Maternal body mass index and the risk of fetal and infant death: a cohort study from the North of England. Hum Reprod 2011; 26: 1501-11.

25. Heslehurst N, Vieira R, Hayes L, Crowe L, Jones D, Robalino S, et al. Maternal body mass index and post-term birth: a systematic review and meta-analysis. Obes Rev 2017; 18: 293-308.

This article is protected by copyright. All rights reserved. 
26. Torloni MR, Betran AP, Daher S, Widmer M, Dolan SM, Menon R, et al. Maternal BMI and preterm birth: a systematic review of the literature with meta-analysis. J Matern Fetal Neonatal Med 2009; 22: 957-70.

27. Correa A, Marcinkevage J. Prepregnancy obesity and the risk of birth defects: an update. Nutr Rev 2013; 71 Suppl 1: S68-77.

28. Stothard KJ, Tennant PW, Bell R, Rankin J. Maternal overweight and obesity and the risk of congenital anomalies: a systematic review and meta-analysis. Jama 2009; 301: 636-50.

29. Blomberg MI, Kallen B. Maternal obesity and morbid obesity: the risk for birth defects in the offspring. Birth Defects Res A Clin Mol Teratol 2010; 88: 35-40.

30. Zhu T, Tang J, Zhao F, Qu Y, Mu D. Association between maternal obesity and offspring Apgar score or cord pH: a systematic review and meta-analysis. Sci Rep 2015; 5: 18386.

31. Villamor E, Tedroff K, Peterson M, Johansson S, Neovius M, Petersson G, et al. Association Between Maternal Body Mass Index in Early Pregnancy and Incidence of Cerebral Palsy. JAMA 2017; 317: 925-36.

32. Blomberg M. Maternal obesity, mode of delivery, and neonatal outcome. Obstet Gynecol 2013; $122:$ 50-5.

33. Hyperglycaemia and Adverse Pregnancy Outcome (HAPO) Study: associations with maternal body mass index. Bjog 2010; 117: 575-84.

34. Barker DJ. The fetal and infant origins of adult disease. BMJ 1990; $3016761: 1111$.

35. Godfrey KM, Reynolds RM, Prescott SL, Nyirenda M, Jaddoe VW, Eriksson JG, et al. Influence of maternal obesity on the long-term health of offspring. Lancet Diabetes Endocrinol 2017; 5: 53-64. 36. Mamun AA, Mannan M, Doi SA. Gestational weight gain in relation to offspring obesity over the life course: a systematic review and bias-adjusted meta-analysis. Obes Rev 2014; 15: 338-47.

37. Sorensen T, Ajslev TA, Angquist L, Morgen CS, Ciuchi IG, Davey Smith G. Comparison of associations of maternal peri-pregnancy and paternal anthropometrics with child anthropometrics

This article is protected by copyright.All rights reserved. 
from birth through age 7 y assessed in the Danish National Birth Cohort. Am J Clin Nutr 2016; 104: $389-96$.

38. Hivert MF, Rifas-Shiman SL, Gillman MW, Oken E. Greater early and mid-pregnancy gestational weight gains are associated with excess adiposity in mid-childhood. Obesity (Silver Spring) 2016; 24: 1546-53.

39. Robinson SM, Crozier SR, Harvey NC, Barton BD, Law CM, Godfrey KM, et al. Modifiable early-life risk factors for childhood adiposity and overweight: an analysis of their combined impact and potential for prevention. Am J Clin Nutr 2015; 101: 368-75.

40. Daraki V, Georgiou V, Papavasiliou S, Chalkiadaki G, Karahaliou M, Koinaki S, et al. Metabolic profile in early pregnancy is associated with offspring adiposity at 4 years of age: the Rhea pregnancy cohort Crete, Greece. PLoS One 2015; 10: e0126327.

41. Castillo H, Santos IS, Matijasevich A. Relationship between maternal pre-pregnancy body mass index, gestational weight gain and childhood fatness at 6-7 years by air displacement plethysmography. Matern Child Nutr 2015; 11: 606-17.

42. Kaar JL, Crume T, Brinton JT, Bischoff KJ, McDuffie R, Dabelea D. Maternal obesity, gestational weight gain, and offspring adiposity: the exploring perinatal outcomes among children study. J Pediatr 2014; 165: 509-15.

43. Oostvogels AJ, Stronks K, Roseboom TJ, van der Post JA, van Eijsden M, Vrijkotte TG. Maternal prepregnancy BMI, offspring's early postnatal growth, and metabolic profile at age 5-6 years: the ABCD Study. J Clin Endocrinol Metab 2014; 99: 3845-54.

44. Gaillard R, Steegers EA, Duijts L, Felix JF, Hofman A, Franco OH, et al. Childhood cardiometabolic outcomes of maternal obesity during pregnancy: the Generation R Study. Hypertension 2014; 63: 683-91.

45. Gaillard R, Steegers EA, Franco OH, Hofman A, Jaddoe VW. Maternal weight gain in different periods of pregnancy and childhood cardio-metabolic outcomes. The Generation R Study. Int J Obes (Lond) 2015; 39: 677-85.

This article is protected by copyright.All rights reserved. 
46. Crozier SR, Inskip HM, Godfrey KM, Cooper C, Harvey NC, Cole ZA, et al. Weight gain in pregnancy and childhood body composition: findings from the Southampton Women's Survey. Am J Clin Nutr 2010; 91: 1745-51.

47. Fraser A, Tilling K, Macdonald-Wallis C, Sattar N, Brion MJ, Benfield L, et al. Association of maternal weight gain in pregnancy with offspring obesity and metabolic and vascular traits in childhood. Circulation 2010; 121: 2557-64.

48. Philipps LH, Santhakumaran S, Gale C, Prior E, Logan KM, Hyde MJ, et al. The diabetic pregnancy and offspring BMI in childhood: a systematic review and meta-analysis. Diabetologia 2011; 54: 1957-66.

49. Schellong K, Schulz S, Harder T, Plagemann A. Birth weight and long-term overweight risk: systematic review and a meta-analysis including 643,902 persons from 66 studies and 26 countries globally. PLoS One 2012; 7: e47776.

50. Boney CM, Verma A, Tucker R, Vohr BR. Metabolic syndrome in childhood: association with birth weight, maternal obesity, and gestational diabetes mellitus. Pediatrics 2005; 115: e290-6.

51. Woo Baidal JA, Locks LM, Cheng ER, Blake-Lamb TL, Perkins ME, Taveras EM. Risk Factors for Childhood Obesity in the First 1,000 Days: A Systematic Review. Am J Prev Med 2016; 50: 761-79. 52. Chavatte-Palmer P, Tarrade A, Rousseau-Ralliard D. Diet before and during Pregnancy and Offspring Health: The Importance of Animal Models and What Can Be Learned from Them. Int J Environ Res Public Health 2016; 13: 586.

53. Myatt L, Maloyan A. Obesity and Placental Function. Semin Reprod Med 2016; 34: 42-9. 54. Zhang L, Long NM, Hein SM, Ma Y, Nathanielsz PW, Ford SP. Maternal obesity in ewes results in reduced fetal pancreatic beta-cell numbers in late gestation and decreased circulating insulin concentration at term. Domest Anim Endocrinol 2011; 40: 30-9.

55. Farley D, Tejero ME, Comuzzie AG, Higgins PB, Cox L, Werner SL, et al. Feto-placental adaptations to maternal obesity in the baboon. Placenta 2009; 30: 752-60.

This article is protected by copyright.All rights reserved. 
56. Zambrano E, Ibanez C, Martinez-Samayoa PM, Lomas-Soria C, Durand-Carbajal M, RodriguezGonzalez GL. Maternal Obesity: Lifelong Metabolic Outcomes for Offspring from Poor Developmental Trajectories During the Perinatal Period. Arch Med Res 2016; 47: 1-12.

57. Wankhade UD, Thakali KM, Shankar K. Persistent influence of maternal obesity on offspring health: Mechanisms from animal models and clinical studies. Mol Cell Endocrinol 2016; 435: 7-19.

58. Tarrade A, Panchenko P, Junien C, Gabory A. Placental contribution to nutritional programming of health and diseases: epigenetics and sexual dimorphism. J Exp Biol 2015; 218: 50-8. 59. Sferruzzi-Perri AN, Camm EJ. The Programming Power of the Placenta. Front Physiol 2016; 7: 33. 60. Mao J, Zhang X, Sieli PT, Falduto MT, Torres KE, Rosenfeld CS. Contrasting effects of different maternal diets on sexually dimorphic gene expression in the murine placenta. Proc Natl Acad Sci US A 2010; 107: 5557-62.

61. Mitanchez D, Jacqueminet S, Nizard J, Tanguy ML, Ciangura C, Lacorte JM, et al. Effect of maternal obesity on birthweight and neonatal fat mass: A prospective clinical trial. PLoS One 2017; 12: e0181307.

62. Watkins AJ, Lucas ES, Fleming TP. Impact of the periconceptional environment on the programming of adult disease. J Dev Orig Health Dis 2010; 1: 87-95.

63. Dahlhoff M, Pfister S, Blutke A, Rozman J, Klingenspor M, Deutsch MJ, et al. Periconceptional obesogenic exposure induces sex-specific programming of disease susceptibilities in adult mouse offspring. Biochim Biophys Acta 2014; 1842: 304-17.

64. Shankar K, Zhong Y, Kang P, Lau F, Blackburn ML, Chen JR, et al. Maternal obesity promotes a proinflammatory signature in rat uterus and blastocyst. Endocrinology 2011; 152: 4158-70.

65. Sasson IE, Vitins AP, Mainigi MA, Moley KH, Simmons RA. Pre-gestational vs gestational exposure to maternal obesity differentially programs the offspring in mice. Diabetologia $2015 ; 58$ : $615-24$

This article is protected by copyright. All rights reserved. 
66. Panchenko PE, Voisin S, Jouin M, Jouneau L, Prezelin A, Lecoutre S, et al. Expression of epigenetic machinery genes is sensitive to maternal obesity and weight loss in relation to fetal growth in mice. Clin Epigenetics 2016; 8: 22.

67. Aagaard-Tillery KM, Grove K, Bishop J, Ke X, Fu Q, McKnight R, et al. Developmental origins of disease and determinants of chromatin structure: maternal diet modifies the primate fetal epigenome. J Mol Endocrinol 2008; 41: 91-102.

68. Waterland RA, Kellermayer R, Laritsky E, Rayco-Solon P, Harris RA, Travisano M, et al. Season of conception in rural gambia affects DNA methylation at putative human metastable epialleles. PLoS Genet 2010; 6: e1001252.

69. Waterland RA, Travisano M, Tahiliani KG, Rached MT, Mirza S. Methyl donor supplementation prevents transgenerational amplification of obesity. Int J Obes (Lond) 2008; 32: 1373-9.

70. Bourdon A, Parnet P, Nowak C, Tran NT, Winer N, Darmaun D. L-Citrulline Supplementation Enhances Fetal Growth and Protein Synthesis in Rats with Intrauterine Growth Restriction. J Nutr 2016; 146: 532-41.

71. Miczke A, Suliburska J, Pupek-Musialik D, Ostrowska L, Jablecka A, Krejpcio Z, et al. Effect of L-arginine supplementation on insulin resistance and serum adiponectin concentration in rats with fat diet. Int J Clin Exp Med 2015; 8: 10358-66.

72. Suliburska J, Bogdanski P, Szulinska M, Pupek-Musialik D, Jablecka A. Changes in mineral status are associated with improvements in insulin sensitivity in obese patients following L-arginine supplementation. Eur J Nutr 2014; 53: 387-93.

73. Heerwagen MJ, Stewart MS, de la Houssaye BA, Janssen RC, Friedman JE. Transgenic increase in N-3/n-6 Fatty Acid ratio reduces maternal obesity-associated inflammation and limits adverse developmental programming in mice. PLoS One 2013; 8: e67791.

This article is protected by copyright.All rights reserved. 
74. Nathanielsz PW, Ford SP, Long NM, Vega CC, Reyes-Castro LA, Zambrano E. Interventions to prevent adverse fetal programming due to maternal obesity during pregnancy. Nutr Rev 2013; 71 Suppl 1:S78-87.

75. Navarro E, Funtikova AN, Fito M, Schroder H. Prenatal nutrition and the risk of adult obesity: Long-term effects of nutrition on epigenetic mechanisms regulating gene expression. J Nutr Biochem 2017; 39: 1-14.

Figure 1: Summary of the major findings from epidemiological studies on the effect of maternal obesity on pregnancy, fetal development, neonatal outcomes and childhood health.

Interestingly, when it was adjusted for maternal BMI, gestational diabetes had no effect on childhood obesity. In contrast, the combination of maternal obesity and excess maternal weight gain or excess fetal growth increased the risks of childhood obesity and metabolic syndrome, respectively. OR: Odd Ratio

This article is protected by copyright All rights reserved. 


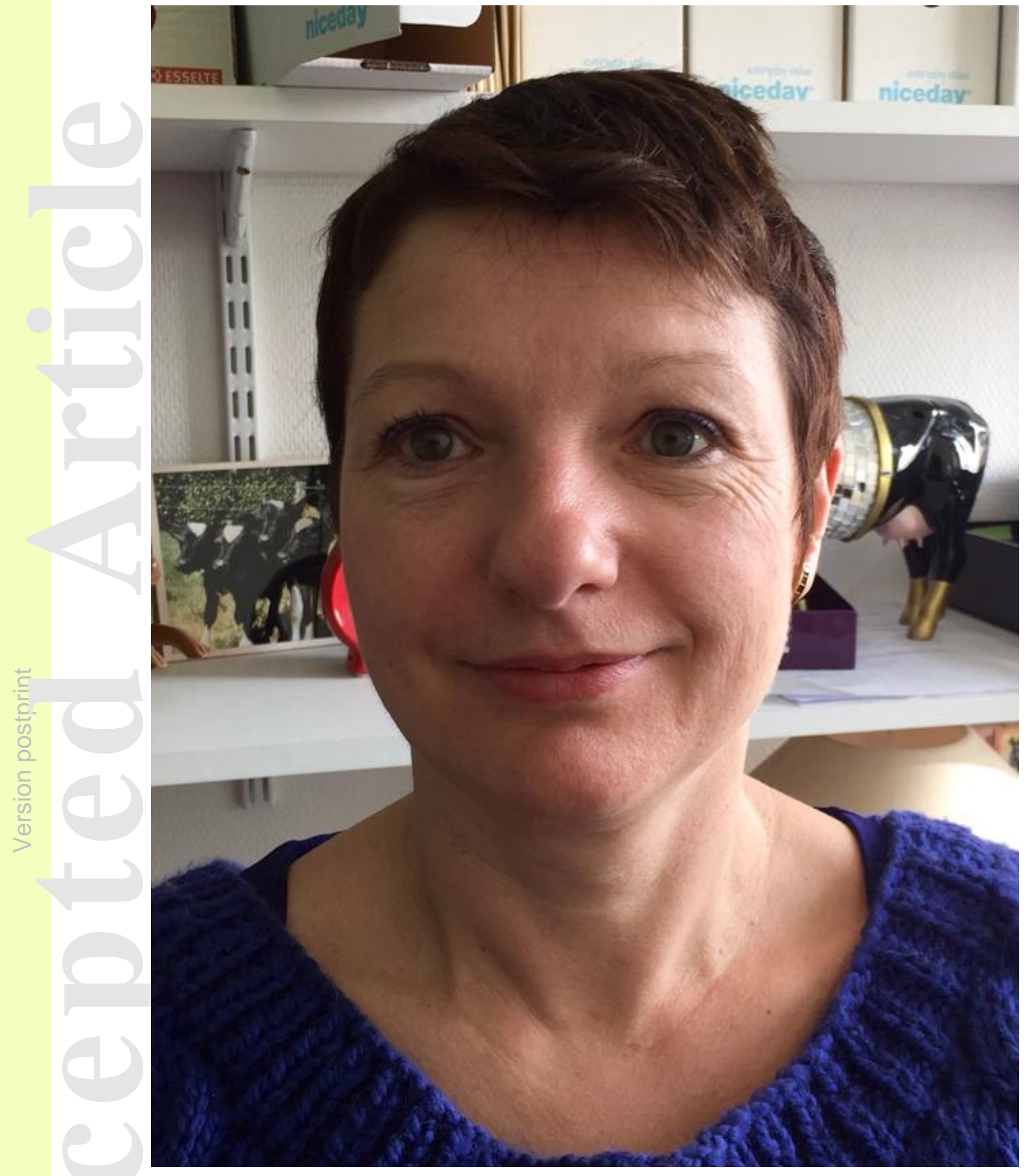

This article is protected by copyright. All rights reserved.

Mitanchez. D.. Chavatte-Palmer. P. (2018). Review shows that maternal obesity induces serious 


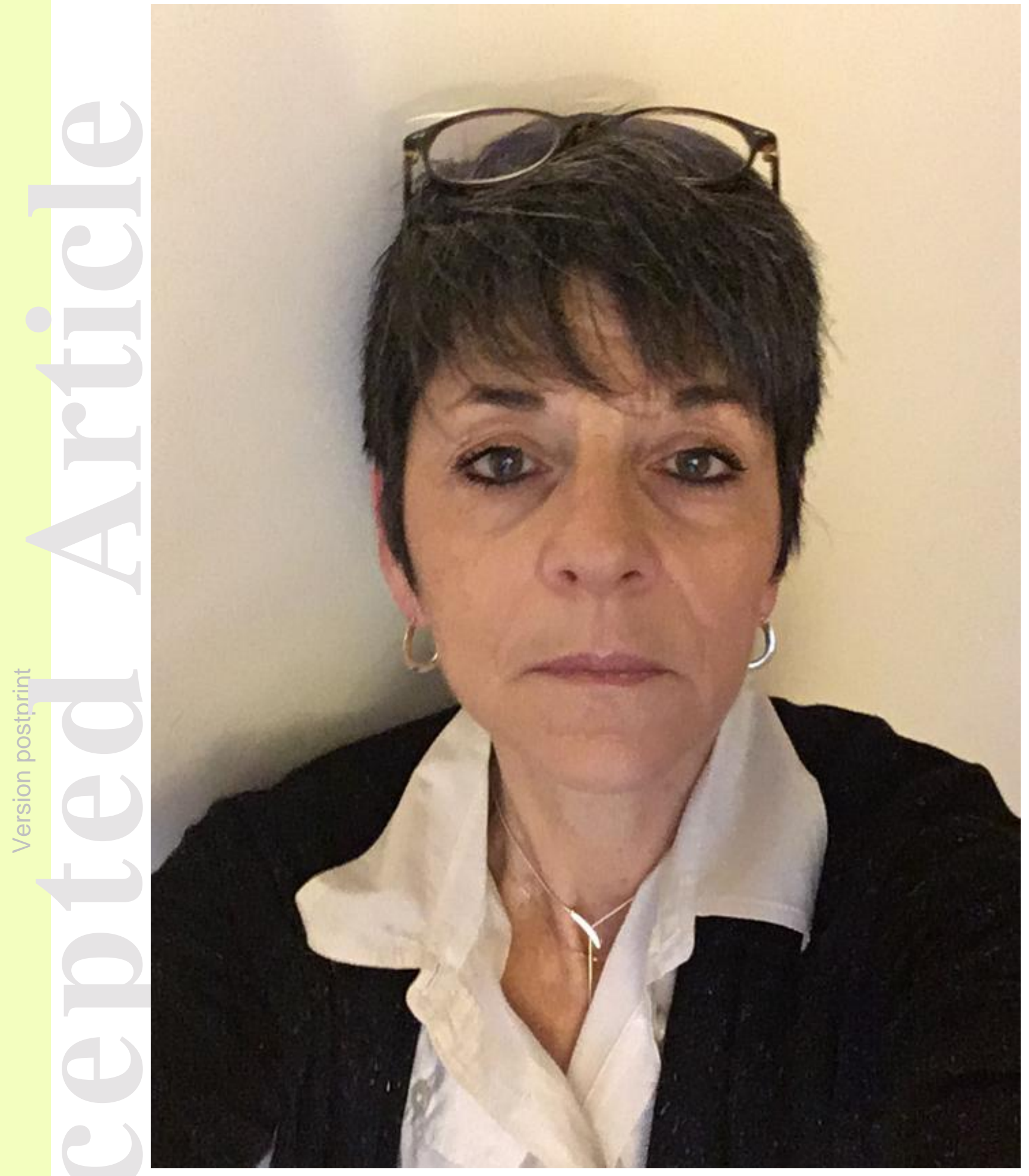

This article is protected by copyright. All rights reserved.

Mitanchez. D.. Chavatte-Palmer. P. (2018). Review shows that maternal obesity induces serious 
Table 1: Association of maternal obesity with high or low birth weight reported from metaanalysis.

\begin{tabular}{|c|c|c|c|}
\hline High birth weight & & Odds ratio & $\begin{array}{c}95 \% \text { confidence } \\
\text { interval }\end{array}$ \\
\hline \multirow[t]{2}{*}{ Liu et al, 2016 (16) } & $\mathrm{BW}>4 \mathrm{~kg}$ & 2.92 & $2.67-3.20$ \\
\hline & $\mathrm{BW}>90^{\text {th }}$ percentile & 1.88 & $1.67-2.11$ \\
\hline \multirow[t]{3}{*}{ Gaudet et al, 2014 (17) } & $\mathrm{BW}>4.5 \mathrm{~kg}$ & 2.77 & $2.22-3.45$ \\
\hline & $\mathrm{BW}>4 \mathrm{~kg}$ & 2.17 & $1.92-2.45$ \\
\hline & $\mathrm{BW}>90^{\text {th }}$ percentile & 2.42 & $2.16-2.72$ \\
\hline \multirow[t]{3}{*}{ Yu et al, 2013 (18) } & $\mathrm{BW}>4.5 \mathrm{~kg}$ & 3.23 & $2.39-4.37$ \\
\hline & $\mathrm{BW}>4 \mathrm{~kg}$ & 2.00 & $1.84-2.18$ \\
\hline & $\mathrm{BW}>90^{\text {th }}$ percentile & 2.08 & $1.95-2.23$ \\
\hline Heslehurst et al, 2008 (19) & High birth weight & 2.36 & $2.29-2.42$ \\
\hline \multicolumn{4}{|l|}{ Low birth weight } \\
\hline Liu et al, 2016 (16) & $\mathrm{BW}<2 \mathrm{~kg}$ & 1.24 & $1.09-1.41$ \\
\hline McDonald et al, 2010 (21) & $\mathrm{BW}<2.5 \mathrm{~kg}$ & 0.84 & $0.75-0.95$ \\
\hline Heslehurst et al, 2008 (19) & Low birth weight & 0.84 & $0.78-0.90$ \\
\hline
\end{tabular}

BW, birth weight.

This article is protected by copyright.All rights reserved. 
Table 2: Association of maternal obesity with preterm birth reported from meta-analyses.

\begin{tabular}{|c|c|c|c|}
\hline Preterm birth $<37$ weeks & & Odds ratio & $\begin{array}{l}95 \% \text { confidence } \\
\text { interval }\end{array}$ \\
\hline Liu et al, 2016 (16) & & 1.05 & $1.05-1.09$ \\
\hline \multirow[t]{3}{*}{ McDonald et al, 2010 (21) } & All & 1.10 & $0.99-1.21$ \\
\hline & $\begin{array}{l}\text { Induced preterm } \\
\text { birth }\end{array}$ & 1.56 & $1.42-1.71$ \\
\hline & $\begin{array}{l}\text { Spontaneous } \\
\text { preterm birth }\end{array}$ & 0.88 & $0.74-1.04$ \\
\hline \multirow[t]{2}{*}{ Torloni et al, 2009 (26) } & All & 0.89 & $0.78-1.01$ \\
\hline & $\begin{array}{l}\text { Induced preterm } \\
\text { birth }\end{array}$ & 1.48 & $1.33-1.65$ \\
\hline Heslehurst et al, 2008 (19) & & 1.23 & $1.15-1.30$ \\
\hline \multicolumn{4}{|l|}{ Preterm birth < 33 weeks } \\
\hline McDonald et al, 2010 (21) & & 1.45 & $1.21-1.71$ \\
\hline \multicolumn{4}{|l|}{ Preterm birth < 32 weeks } \\
\hline \multirow[t]{2}{*}{ Torloni et al, 2009 (26) } & All & 1.48 & $1.20-1.81$ \\
\hline & $\begin{array}{l}\text { Induced preterm } \\
\text { birth }\end{array}$ & 2.00 & $1.47-2.73$ \\
\hline Heslehurst et al, 2008 (19) & All morbidly obese & 1.59 & $1.47-1.71$ \\
\hline
\end{tabular}

This article is protected by copyright. All rights reserved. 
Table 3: Association of obesity or adiposity in childhood with maternal obesity and excessive gestational weight gain reported from prospective cohorts.

\begin{tabular}{|c|c|c|c|c|}
\hline & Country & $\begin{array}{l}\text { Sample } \mathbf{n} \\
\text { /mean age at } \\
\text { investigation }\end{array}$ & $\begin{array}{l}\text { Risk associated } \\
\text { with maternal } \\
\text { obesity }\end{array}$ & $\begin{array}{l}\text { Risk associated } \\
\text { with excessive } \\
\text { gestational } \\
\text { weight gain } \\
\text { (GWG) }\end{array}$ \\
\hline $\begin{array}{l}\text { Sorensen et } \\
\text { al, } 2016 \text { (37) }\end{array}$ & Denmark & 30566 / 7 years & $\begin{array}{l}\mathrm{OR}=2.34,95 \% \\
\mathrm{Cl} 2.05-2.68\end{array}$ & \\
\hline $\begin{array}{l}\text { Hivert et al, } \\
2016 \text { (38) }\end{array}$ & Massachusetts & 989 / 7.7 years & & $\begin{array}{l}\text { First trimester: OR } \\
=1.31,95 \% \mathrm{Cl} \\
1.10-1.55\end{array}$ \\
\hline $\begin{array}{l}\text { Robinson et } \\
\text { al, } 2015 \text { (39) }\end{array}$ & $\begin{array}{l}\text { United } \\
\text { Kingdom }\end{array}$ & 991 / 6 years & $\begin{array}{l}\beta=0.70,95 \% \mathrm{Cl} \\
0.50-0.90\end{array}$ & $\begin{array}{l}\beta=0.32,95 \% \mathrm{Cl} \\
0.18,0.47\end{array}$ \\
\hline $\begin{array}{l}\text { Daraki et al, } \\
2015(40)\end{array}$ & Greece & $618 / 4$ years & $\begin{array}{l}\mathrm{OR}=1.83,95 \% \\
\mathrm{Cl} 1.18-2.81\end{array}$ & \\
\hline $\begin{array}{l}\text { Castillo et al, } \\
2015(41)\end{array}$ & Brazil & 3156 / 6 years & $\begin{array}{l}+1 \mathrm{~kg} / \mathrm{m}^{2} \text { in } \\
\text { maternal BMl: } \\
+0.18 \% \text { body fat } \\
\%\end{array}$ & $\begin{array}{l}+1 \mathrm{~kg} \text { in GWG: } \\
+0.18 \% \text { body fat } \%\end{array}$ \\
\hline $\begin{array}{l}\text { Kaar et al, } \\
2014 \text { (42) }\end{array}$ & Colorado & $\begin{array}{l}313 / 10.4 \\
\text { years }\end{array}$ & $\begin{array}{l}\text { Each }+1 \mathrm{~kg} / \mathrm{m}^{2} \text { in } \\
\text { maternal } \mathrm{BMI}^{*} \text { : } \\
\beta=0.13,95 \% \mathrm{Cl} \\
0.02-0.25\end{array}$ & $\begin{array}{l}\text { Each }+1 \mathrm{~kg} / \mathrm{m}^{2} \text { in } \\
\text { maternal } \mathrm{BMI}^{*} \text { : } \\
\beta=0.34,95 \% \mathrm{Cl} \\
0.25-0.44\end{array}$ \\
\hline $\begin{array}{l}\text { Oostvogels et } \\
\text { al, } 2014(43)\end{array}$ & Netherlands & $\begin{array}{l}3321 / 5.7 \\
\text { years }\end{array}$ & $\begin{array}{l}\text { Waist-height-ratio: } \\
\beta=0.199,95 \% \\
\text { Cl } 0.097-0.300\end{array}$ & \\
\hline $\begin{array}{l}\text { Gaillard et al, } \\
2014(44)\end{array}$ & Netherlands & 4871 / 6 years & $\begin{array}{l}\text { OR }=3.84,95 \% \\
\mathrm{Cl} 3.01-4.90\end{array}$ & \\
\hline
\end{tabular}

This article is protected by copyright. All rights reserved. 


\begin{tabular}{|c|c|c|c|}
\hline $\begin{array}{l}\text { Gaillard et al, } \\
2015 \text { (45) }\end{array}$ & Netherlands & 5908 / 6 years & $\begin{array}{l}\text { GWG in early } \\
\text { pregnancy: } \\
\text { OR }=1.19,95 \% \mathrm{Cl} \\
1.10-1.29\end{array}$ \\
\hline $\begin{array}{l}\text { Crozier et al, } \\
2010(46)\end{array}$ & $\begin{array}{l}\text { United } \\
\text { Kingdom }\end{array}$ & 948 / 6 years & $\begin{array}{l}\text { Excess GWG } \\
\text { according to IOM: } \\
\beta=0.30,95 \% \mathrm{Cl} \\
0.11-0.49\end{array}$ \\
\hline $\begin{array}{l}\text { Frazer et al, } \\
2010(47)\end{array}$ & $\begin{array}{l}\text { United } \\
\text { Kingdom }\end{array}$ & 5154 / 9 years & $\begin{array}{l}>500 \mathrm{~g} / \text { weeks, < } \\
14 \text { weeks }: \\
+0.624,95 \% \mathrm{Cl}: \\
0.241-1.007 \\
>500 \mathrm{~g} / \mathrm{week}^{\pi}, 14- \\
36 \text { weeks }{ }^{\pi}: \\
+0.623,95 \% \mathrm{Cl}: \\
0.257-0.989\end{array}$ \\
\hline
\end{tabular}

IOM: Institute of Medicine, OR: odd ratio, Cl: confidence interval, $\beta$ : regression coefficient

*Association with maternal pre-pregnancy BMI when gestational weight gain was adequate or excessive, according to the Institute of Medicine recommendations.

"Mean difference (95\% confidence interval) in offspring BMI per 1-kg change in maternal pre-pregnancy weight and $400 \mathrm{~g} /$ week gestational weight gain.

This article is protected by copyright.All rights reserved. 


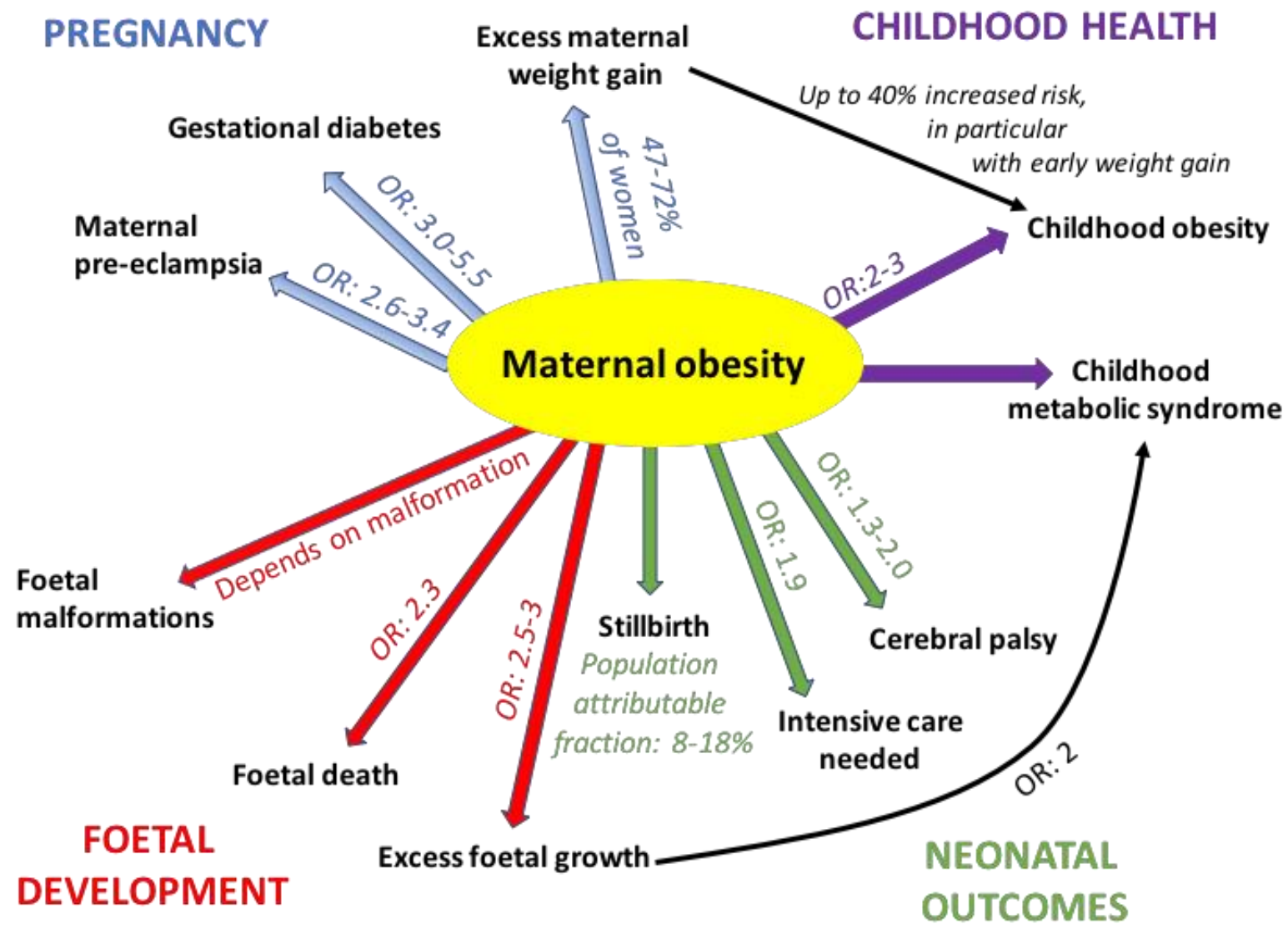

Figure 1

This article is protected by copyright All rights reserved. 